ljtihad: Jurnal Wacana Hukum Islam dan Kemanusiaan

Vol. 18, No. 2 (2018), pp. 227-249, doi : 10.18326/ijtihad.v18i2.227-249

\title{
Peran sumber daya manusia (SDM) dalam perkembangan perbankan syariah: analisis kualitas dan kinerja pegawai
}

\author{
Nilam Sari, Abrar Amri \\ UIN Ar-Raniry Banda Aceh \\ E-mail: nilam.sari@ar-raniry.ac.id, abrar.amri@ar-raniry.ac.id \\ DOI: 10.18326/ijtihad.v18i2.227-249
}

Peran Sumber daya manusia sangat dibutuhkan dalam suatu organisasi bila dibandingkan dengan sumber daya lainnya. Keberhasilan suatu organisasi atau perusahaan dalam mencapai tujuan yang telah ditetapkan merupakan hasil dari kinerja karyawan dalam perusahaan tersebut. Penelitian ini membahas pengaruh kualitas sumber daya manusia terbadap kinerja karyawan perbankan syariah di Aceh dan bagaimana upaya sebaiknya dilakukan dalam meningkatkan kualitas sumber daya manusia perbankan syariah di Aceh. Metode penelitian yang digunakan adalah metode campuran (Mixed Method). Berdasarkan uji variabel diperoleh $\mathrm{t}_{\text {hitung }}$ sebesar 3,895 dan $t_{\text {tabel }}$ sebesar 2,048 hal ini menunjukkan bahwa $t_{\text {hitung }}>t_{\text {tabel }}$ dengan nilai signifikansi sebesar 0,001 atau nilai probabilitas $\alpha=5 \%$. Berdasarkan hasil perhitungan statistik menyatakan bahwa variabel kualitas sumberdaya manusia mempunyai pengaruh yang signifikan terhadap kinerja karyawan. Dalam artian semakin tinggi kualitas sumber daya manusia maka akan semakin tinggi pula kinerja karyawan pada perbankan syariah. Kualitas sumber daya manusia dalam perbankan dapat ditingkatkan melalui: 1) Evaluasi kurikulum ekonomi syariah yang berkesinambungan di lembaga pendidikan perguruan tinggi. 2) Mendirikan fakultas/program studi ekonomi Islam sesuai dengan kebutuhan pasarperbankan syariah. 3) Perguruan Tinggi bekerjasama dengan Bank Indonesia Melaksanakan pendidikan dan pelatiban ekonomi Islam bagi mahasiswa dan karyawan bank syariah. 5) Pendidikan dan pelatihan tentang perbankan untuk. meningkatkan mutu sumber daya manusia perbankan syariah adalab upaya jangka pendek yang dapat dilakukan dalam waktu dekat. Sedangkan untuk waktu jangka panjang mengembangkan pendidikan yang bersinerji antara tiga indikator yang sangat berperan yaitu lembaga perbankan, perguruan tinggi dan pemerintah.

Human resources have a very important role in a company organization especially when compared to other resources. Employee performance is a very important thing in an effort to achieve change in order to achieve its goals. This study discusses the influence of the quality of human resources on the performance of sharia banking employees in Aceh and how efforts should be made in improving the quality of sharia banking human resources in Aceh. The research method used is a 
mixed method (Mixed Method). Based on test variables obtained by t count of 3.859 while $t$ table of 2.048 the results of this calculation indicate that $t$ count $>t$ table with a significance level of 0.001 or probability above $\alpha=5 \%$. Thus the results of statistical calculations indicate that the variable quality of human resources has a significant influence on employee performance. Which means that the higher the quality of human resources, the higher the performance of employees in Islamic banking. Efforts to improve the quality of banking Human Resources can be done through: 1) Evaluation of a sustainable Islamic economic curriculum in higher education institutions. 2) Establish a faculty / Islamic economic study program in accordance with the needs of the Islamic banking market. 3) Higher Education collaborates with Bank Indonesia to carry out Islamic economic education and training for students and employees of Islamic banks. 5) Education and training on banking to improve the quality of human resources in sharia banking is a short-term effort that can be done now. While the efforts made in the long term are by organizing education that is synergized between the education provider (college) user (bank) and the person in charge of education (government).

Keywords: Human resources; quality; employee performance; Islamic bank

\section{Pendahuluan}

Suatu organisasi akan memperoleh kesuksesan melalui potensi yang dimiliki oleh manusia dalam mencapai tujuan sebagaimana yang telah direncanakan. Dengan kata lain organisasi akan berhasil salah satu faktor yang menentukan dalam mencapai tujuannya adalah sumber daya manusia. Melayu S.P. Hasibuan (2003: 10) menyatakan bahwa manusia memiliki peran dan aktif dan mendominasi dalam setiap kegiatan organisasi disebabkan manusia adalah sebagai perancang, pemeran dan penentu tercapainya tujuan suatu organisasi.

Veithzal Rivai (2005: 309) menyatakan bahwa "Kemampuan bekerja pegawai merupakan suatu hal yang sangat bermanfaat dalam upaya menggapai perubahan guna meraih sasaran yang ditujunya." Kemudian, Veithzal Rivai juga menambahkan bahwa "kinerja pegawai akan mencerminkan kinerja organisasi berdasarkan hasil dari capaian organisasi" maka dapat dilihat bahwa terdapat hubungan yang sangat erat antara kinerja institusi (institutional performance) dengan kinerja perorangan (individual performance), dengan perkataan lain kinerja seorang pegawai (individual performance) baik, maka terdapat peluang besar bagi kinerja organiasi (institutional performance) juga baik._

Untuk melahirkan sumber daya manusia yang berkualitas dibutuhkan upaya yang terorganisasi, berkesinambungan serta menyeluruh, salah satunya adalah melalui pemberdayaan. Sedarmayanti (2001: 1) menyatakan pemberdayaan adalah kemampuan yang lebih baik dari 
sebelumnya apakah dalam hal kesanggupan (competency), wewenang (authority), tanggung jawab (responsibility) individual yang dimiliki oleh seseorang. Peran Sumber daya manusia (SDM) dalam suatu organisasi sangat strategis karena keberhasilan organisasi untuk mencapai tujuan yang sudah ditetapkan ditentukan oleh faktor sumber daya manusianya. Dalam upaya pemberdayaan SDM komponen-komponen yang perlu mendapat perhatian adalah sebagai berikut: 1) Penempatan pegawai berdasarkan kemampuan yang dimiliki oleh pegawai serta sesuai dengan tuntutan kebutuhan dalam organisasi. 2) Pengetahuan, keterampilan, dan sikap atau prilaku pegawai yang memadai, 3) Dukungan atasan terhadap pegawai, 4) Kepemimpinan, 5) Motivasi. 6)Kewenangan serta tanggung jawab yang jelas, 7) Kepercayaan terhadap pegawai.

Lembaga keuangan syariah seperti bank syariah dikelola dengan prinsip syariah. Lahirnya perbankan syariah disebabkan oleh kondisi obyektif dengan adanya keinginan masyarakat untuk berkegiatan ekonomi yang berprinsipkan syariah, diantaranya melalui perbankan syariah. Bank syariah di Indonesia berkembang sangat cepat, hal ini didukung oleh hadirnya manajemen sumber daya manusia (SDM) yang berkualitas. Sebab, bank syariah tidak mungkin mampu mencapai kesuksesan kecuali didukung oleh manajemen sumber daya manusia yang berkualitas. Hingga kini, diantara permasalahan yang masih dihadapi perbankan syariah adalah: SDM yang berlatar belakang pengetahuan dalam bidang perbankan syariah masih relatif sedikit dibandingkan dengan ekonomi konvensioal.

Perkembangan Perbankan syariah perlu didukung oleh sumber daya manusia (SDM) yang layak, baik dari segi kuantitas maupun dari segi kualitasnya. Namun, faktanya SDM yang tidak memiliki latar belakang pengetahuan Islamic Banking masih banyak terlibat dalam institusi syariah. Tentunya kondisi ini sangat signifikan berpengaruh terhadap produktivitas dan profesionalisme perbankan syariah (Cut Nur Halimah, 2016). Hal serupa yang dinyatakan oleh Odie Rizki, beberapa permasalah yang menjadi kendala berkembangnya lembaga keuangan syariah, dan telah menjadi tujuh isu strategis dalam pengembangan lembaga keuangan: 1) Masih sangat kurang konsistensi visi dan koordinasi antara pemerintah dan perbankan . 2) Proporsi industri dan individual bank yang masih kecil serta efisiensi yang rendah, serta modal yang belum memadai 3) Biaya dana yang tinggi mengakibatkan segmen pembiayaan yang seadanya , 4) Kurang inovatif produk serta pelayanan yang belum sesuai dengan harapan masyarakat, 5) SDM secara Kuantitas dan kualitas masih rendah serta 
teknologi sistem informasi yang belum dapat mendukung pengembangan produk layanan,

6) Tingkat pengetahuan dan pemahaman masyarakat yang masih rendah, 7) Belum optimal system pengaturan dan pengawasan (Odie Rizki, 2016).

Lembaga perbankan syariah tumbuh begitu pesat, penyiapan sumber daya manusia yang siap pakai dalam industri ekonomi syariah di masa yang akan datang menjadi satu keharusan. Pada tahun 2012 Sumber Daya Insani ekonomi Syariah yang tersedia hanya sekitar 20.000 orang. Sedangkan pasar tenaga kerja Indonesia memerlukan sekitar 50.000 tenaga kerja terlatih di bidang ekonomi, perbankan konvensional dan perbankan syariah, data tersebut sebagaimana yang dihimpun oleh Institute for Management and Islamic Economic Development (IMIE). Hal ini menunjukkan terdapat peningkatan akan kebutuhan tenaga kerja terlatih di bidang ekonomi syariah tentunya Islamic Banking (IMIE, 2012). Siti Fajriyah , Mantan Deputi Gubernur BI, menyatakan bahwa kemajuan perbankan syariah secara kuantitatif, belum disertai dengan kesiapan SDM yang memadai. Bank syariah membutuhkan 40.000 sumber daya manusia pertahun. Ketika alumni ekonomi syariah sangat terbatas, membuat bank syariah khususnya yang office channeling menerima pegawai dari bank konvensional (TIM UI, 2008).

Sebagaimana penelitian yang dilakukan oleh Universitas Indonesia (UI), Wahyu Dwi Agung, M.Syakir Sula , mengemukakan hasil penelitan bahwa lebih dari sembilan puluh persen sumber daya manusia bank syariah saat ini tidak memiliki background pendidikan ekonomi syariah. SDM lulusan pendidikan ekonomi syariah yang bergelut di industri perbankan syariah hanya tersedia sepuluh persen saja sedangkan sembilan puluh persen lagi memiliki background dari industri perbankan konvensional yang ditransfer untuk bekerja di perbankan syariah (Euis Amalia dkk, 2012).

Berdasarkan permasalahan diatas, penelitian ini akan mengkaji hal sebagai berikut: Pertama, adakah pengaruh kualitas Sumber Daya Manusia (SDM) dalam meningkatkan kinerja karyawan Perbankan Syariah di Aceh? Kedua, bagaimanakah upaya sebaiknya dilakukan dalam meningkatkan kualitas Sumber Daya Manusia Perbankan Syariah di Aceh?

\section{Sumber daya manusia, perbankan syariah dan kinerja karyawan: kajian teoritik}

Buchari Zainun mengemukakan bahwa manajemen SDM merupakan hakikat dari manajemen itu sendiri. Sumber daya manusia (buman resources) adalah sumber daya yang berperan penting 
dalam manajemen. Manusia tetap mememiliki peranan yang sangat penting dalam mencapai kesuksesan suatu organisasi meskipun saat ini teknologi telah berkembang sangat pesat (Buchari Zainun, 2002: 17).

Saat ini ,Sumber daya manusia tidak lagi dilihat hanya sebagai sumber daya belaka, namun dapat menjadi modal atau aset bagi institusi atau organisasi. Oleh karenanya muncul istilah baru di luar H.R. (Human Resources), yaitu H.C. atau Human Capital. SDM dilihat tidak sebatas aset utama saja, tetapi sebagai aset yang bernilai tinggi serta dapat dilipat gandakan, dikembangkan (bandingkan dengan portfolio investasi) dan juga bukan sebaliknya sebagai liability (beban, cost). Bagi sebuah institusi SDM dipandang lebih terkemuka dibandingkan dengan sumber daya lainnya (Charles R Greer, 1995).

Manajemen SDM meliputi pemograman, pengarahan, pengorganisasian, pengawasan kegiatan yang dilakukan, pengadaan, pemberian kompensasi, pengembangan, pemeliharaan sumber daya manusia agar tujuan dari individu, organisasi atau perusahaan dan masyarakat dapat terealisasi. Manajeman sumber daya manusia befungsi sebagai pemikat, penyeleksi, pengguna, pemelihara dan pengembangan organisasi (Soekidjo Notoatmodjo, 1998: 73).

Pada masa lalu SDM bersifat administratif, transaksional dan operasional. Peran SDM dianggap sulit dikuantifikasi, dilihat dan bersifat jangka panjang jika dianggap sebagai investasi. Berbeda dengan saat ini, fungsi dan peran SDM dalam suatu organisasi atau perusahaan telah mendapat perhatian dalam menjalankan kegiatannya (Ulrich, 1998: 25).

Sumber daya manusia adalah perpaduan kemampuan dari daya pikir dan daya fisik yang dimiliki oleh setiap manusia, lingkungan dan keturunannya akan menentukan sifat dan perilaku manusia, sedangkan prestasi kerja didorong oleh keinginan untuk memenuhi kepuasannya. Peranan manusia semakin bernilai keberadaannya dalam suatu perusahaan. Hal ini agar tujuan suatu perusahaan dapat terealisasi maka manusia perperan aktif dalam mengoperasikan perusahaan. Meskipun kemajuan teknologi yang sangat pesat akan tetapi peran manusia dalam perusahaan tetap bermakna. Kemajuan teknologi tidak dapat menyingkirkan Peran sumber daya manusia dalam perusahaan karena masih ada perihal yang tidak dapat dilakukan oleh teknologi.

Kemampuan berfikir, perasaan dan tingkah laku manusia menunjukkan manusia berbeda dari sumber daya lainnya, sebab itu agar SDM dapat di kelola dengan baik dan efesien di 
butuhkan kapabel yang baik dalam manajemen SDM. Dari penjelasan tersebut diatas dapat dikatakan bahwa manajemen SDM merupakan proses pendayagunaan manusia atau pegawai yang mencakup; 1)penerimaan, 2)penggunaan, 3)pengembangan dan pemeliharaan sumber daya manusia yang telah ada.

\section{Kualitas Sumber Daya Manusia}

Menurut M. Dawan Raharjo dalam buku yang ditulisnya dengan judul "Intelektual, Intelegensia dan perilaku politik bangsa", beliau mengemukakan bahwa kualitas sumber daya manusia itu ditentukan oleh pendidikan atau kadar pengetahuan, pengalaman atau kematangan dan sikapnya serta nilai-nilai yang dimilikinya tidak hanya ditentukan oleh aspek kekuatan tenaga fisiknya atau keterampilan saja". Beliau juga mengatakan bahwa aspek biologi juga memiliki peran dan arti penting bagi peningkatan kualitas sumber daya manusia. Kualitas Sumber daya manusia dalam buku Soekidjo Notoatmodjo yang berjudul "Pengembangan Sumber Daya Manusia”, mengatakan bahwa: “Kualitas SDM adalah keterkaitan antara dua dimensi yaitu dimensi fisik (kualitas fisik) dan dimensi non fisik (kualitas non fisik) yang mampu berfikir, berusaha dan kompeten".

Menurut Bambang, Pengertian Kualitas sumber daya manusia adalah kemampuan yang dimiliki oleh karyawan yang mengarah pada intelijensi kemampuan berfikir serta berwawasan luas. Memiliki keterampilan artinya kemampuan yang dimiliki karyawan dalam menguasai teknis operasional pada bidang tertentu . Memiliki kemampuan artinya daya yang terbentuk dari beberapa keahlian yang dimiliki oleh seorang karyawan yang meliputi tanggung jawab komitmen, ketertiban, kerjasama . Bambang Hariadi (2005: 205)

Dengan demikian dapat ditarik kesimpulan bahwa yang dimaksud dengan kualitas sumber daya manusia adalah perpaduan antara kualitas fisik (kesehatan) dan kualitas non fisik (keterampilan danpengetahuan).

\section{Perbankan Syariah}

Perbankan adalah setiap perusahaan yang bergerak di bidang perbankan, menghimpun dan menyalurkan dana, artinya kegiatan yang dilakukan oleh lembaga perbankan selalu berkaitan dengan bidang perbankan, apakah kegiatannya hanya menghimpun atau hanya menyalurkan dana atau bahkan kedua-duanya yakni menghimpun dan menyalurkan dana 
(Kashmir, 2001: 17).

Dalam UU Nomor 21 Tahun 2008 tentang perbankan syariah, bank syariah adalah bank yang melaksanakan operasional bisnisnya berazaskan dengan prinsip syariah dan menurut jenisnya terdiri atas bank umum syariah dan bank pembiayaan rakyat syariah (UU, 2008). Sebagaimana juga dalam UU Nomor 10 Tahun 1998 tentang perubahan atas undang-undang nomor 7 tahun 1992 tentang perbankan, bank syariah adalah bank umum yang menjalankan kegiatan usaha berdasarkan prinsip syariah yang dalam operasionalnya memberikan jasa lalu lintas pembayaran (UU, 1998).

Dengan demikian bank syariah adalah bank yang beroperasi mengikuti ketentuan aturan syariah. Tata cara operasinya mengacu pada Al Quran dan Hadits . Beroperasi mengikuti perintah dan menjauhi larangan-larangan yang tercantumkan didalam Quran dan Hadits. Praktik muamalah yang diperkirakan mengandung unsur riba gharar dan maisir harus dihindari.

Sejak krisis ekonomi tahun 1997 Bank syariah mampu bertahan ditengah tingginya nilai tukar dan suku bunga . Dalam operasionalnya Bank syariah memiliki karakteristik seperti melarang spekulatif (maysir). transaksi yang tidak transparan (gharar),bunga (riba). Di Indonesia pengembangan perbankan syariah merupakan bagian dari penyehatan sistem perbankan yang dapat meningkatkan daya tahan perekonomian nasional sehingga perekonomian sektor keuangan sejalan dengan pertumbuhan sektor riil tidak hanya bentuk konsekuensi dari UU No. 10/1998 dan UU No. 23/1999.

\section{Kinerja Karyawan}

Pengertian kinerja adalah "hasil usaha yang dicapai secara kuantitas dan kualitas dan oleh seorang pegawai dalam menjalankan tugas sesuai dengan amanah yang diembankan kepadanya". Mangkunegara, Anwar Prabu (2000: 164). Menurut Hadari Nawawi (2000: 89), kinerja ialah: "hasil dari kecakapan bekerja seorang pegawai baik yang bersifat fisik ataupun non fisik”. Faustino Cardoso Gomes (2000) mengutip dari Bernaden dan Russel, kinerja diartikan sebagai: "Outcome yang diperoleh dari peranan suatu pekerjaan tertentu atau kegiatan yang dilaksanakan oleh karyawan selama kurun waktu tertentu.

Kinerja karyawan merupakan tingkat pencapaian karyawan secara menyeluruh dalam kurun waktu tertentu saat menjalankan kewajiban kerjanya dengan berbagai kemungkinan, 
seperti standar hasil kinerja, sasaran, target, atau kriteria yang telah ditentukan sedari awal (Rivai \& Basri, 2005: 14). Penilaian terhadap kinerja karyawan perlu dilakukan supaya dapat mengetahui kinerja karyawan dalam menjalankan tugas yang telah menjadi tanggung jawabnya dengan merujuk pada isi pekerjaan yang telah dilakukan dan harapan dari pencapaian setiap dimensi dalam pekerjaan. Hal ini bertujuan untuk menilai seberapa baik karyawan dalam menjalankan tugasnya dan apa yang perlu dilakukan agar menjadi lebih baik dimasa yang akan datang (Rivai dan Basri, 2005: 77).

Aspek yang dipakai dalam menilai kinerja pegawai adalah pemahaman dan pengetahuan atas pekerjaan, dimensi yang digunakan dalam melakukan penilaian kinerja karyawan adalah wawasan dalam pekerjaan, program dan organisasi, kualitas pekerjaan, produktivitas, pemahaman teknis, komunikasi, kerjasama, kemampuan menjadi lebih baik, tepat waktu, komunikasi, tata laksana proyek dan kepemimpinan. Ukuran prestasi yang lebih sederhana terdapat tiga kriteria untuk mengukur kinerja, 1) pekerjaan berkualitas yang dihasilkan ,2) kuantitas pekerjaan yang sudah dilakukan, 3) Ketepatan waktu yaitu kesesuaiannya dengan waktu yang telah ditetapkan. Suyadi Prawirosentono (1999: 236)

Istilah Performance appraisal adalah penilaian kinerja karyawan. Mangkunegara Anwar Prabu mengutip pendapat Leon C.Minggison Performance appraisal adalah "Suatu metode yang digunakan pimpinan untuk mengetahui apakah seorang karyawan melaksanakan tugasnya sesuai dengan yang diinginkan". Penilaian karyawan adalah merupakan evaluasi yang tersusun dari kerja karyawan dan pengembangan potensi. Maka dapat ditarik kesimpulan bahwa penilaian kinerja adalah suatu metode penilaian terhadap kinerja karyawan yang diamanahkan terhadapnya oleh pimpinan perusahaan secara analitis. Melalui atasan karyawan langsung maupun tidak langsung. Personalia dengan data yang dimiliki dapat menilai kinerja karyawannya.

\section{Metode penelitian}

Metode Penelitian ini adalah dengan menggunakan metode campuran (Mixed Method). Metode ini memadukan pendekatan kuantitatif dan kualitatif dalam hal metodologi (seperti dalam tahap pengumpulan data), kajian model mencampurkan dua pendekatan disemua tahapan prosedur penelitian (Sugiyono, 2013: 404). Mixed Method yang dipakai dalam penelitian ini 
ialah susunan analisis kualitatif dan kuantitatif yang bertujuan untuk mengindentifikasikan sub konsep melalui analisis data kuantitatif dan selanjutnya mengumpulkan data kualitatif untuk memberikan informasi yang telah ada (Sugiyono, 2013: 405). Arti metode campuran Mixed Method adalah untuk menyatukan data kualitatif dan kuantitatif agar memperoleh hasil analisis yang lebih lengkap. Metode kuantitatif berfungsi untuk mencari informasi yang terukur mengenai gambaran kualitas SDM dan kinerja karyawan serta pengaruh antara keduanya pada perbankan syariah di Indonesia. Permasalahan pertama sampai ketiga akan dijawab dengan metode kuantitatif. Beda halnya dengan motode kualitatif yang digunakan untuk memperoleh informasi mengenai upaya meningkatkan kualitas SDM perbankan syariah.

Lokasi Penelitian pada Bank Muamalat, Bank Syariah Mandiri (BSM) dan Bank Aceh di Provinsi Aceh. Populasi dalam penelitian ada dua macam yaitu populasi secara umum dan populasi secara target "target population”. Populasi yang menjadi sasaran dapat diambil kesimpulan dalam sebuah penelitian disebut dengan populasi target (Sukmadinata, 2007: 250). Penelitian ini mengambil sampel seluruh pimpinan dan karyawan Bank Aceh syariah, BSM, dan Bank Muamalat. Sampel penelitian, menurut Suharsimi Arikuntoro, sebagian atau yang mewakili populasi yang diteliti disebut dengan sampel. Oleh sebab itu penelitian tidak dapat dilakukan atas semua populasi kecuali hanya sebagian dari populasi tersebut. "Jika subyek yang diteliti kurang dari 100, maka lebih bagus semuanya diambil, sehingga penelitiannya merupakan penelitian populasi. Namun jika subyek yang diteliti lebih dari 100 maka sampel dapat diambil antara 10-15\% atau 20-25\%" (Suharsimi Arikunto, 1993: 108). Dalam penelitian ini, peneliti menggunakan sampel 10\% dari populasi yang ada pada masing bank syariah yang telah dipilih menjadi objek penelitian Bank Muamalat, BSM dan Bank Aceh Syariah.

Analisis data kuantitatif untuk mengetahui pengaruh kualitas SDM terhadap kinerja karyawan bank syariah melalui uji kolerasi dan regresi. Analisis korelasi (hubungan) digunakan untuk melihat apakah terdapat hubungan antara kualitas sumber daya manusia dengan kinerja karyawan bank syariah. Jika ada hubungan antar variabel, maka seberapa kuat pengaruh antar variabel tersebut. Keeratan antar variabel tersebut dinamakan koefesien kolerasi. Penelitian ini menggunakan model regresi sederhana yaitu model regresi yang hanya menggunakan satu variabel bebas. Tingkat signifikansi pengaruh kualitas SDM terhadap kinerja karyawan dapat diketahui dengan dilakukan uji Anova yang akan menunjukkan regresi secara statistik apakah 
ljtihad: Jurnal Wacana Hukum Islam dan Kemanusiaan, Volume 18, No. 2, Desember 2018: 227-249

signifikan atau tidak dengan melihat angka signifikansinya (Sig). Apabila nilai signifikansinya lebih keci dari $\alpha=0.05$, maka disimpulkan bahwa terjadi hubungan yang signifikan antar variabel. Begitu pula sebaliknya, jika nilai signifikansinya lebih beasr dari $\alpha=0.05$, maka disimpulkan tidak terdapat pengaruh yang signifikan antar variabel.

\section{Kualitas sumber daya manusia dan kinerja karyawan: analisis deskriptif}

Analisis deskriptif merupakan gambaran terhadap kecenderungan responden dalam menjawab intensitas item-item pernyataan di dalam kuesioner. Analisis deskriptif terhadap variabel dalam penelitian ini yaitu: Kualitas Sumber Daya Manusia ( serta Kinerja Karyawan Skala interval yang digunakan dalam penelitian ini untuk dan menggunakan skala likert.

\section{Kualitas Sumber Daya Manusia}

Untuk melihat tanggapan responden terhadap item-item pernyataan yang terdapat pada variabel kualitas sumber daya manusia dapat dilihat pada Lampiran Tanggapan Responden untuk Kualitas Sumber Daya Manusia. Tanggapan responden terhadap kualitas sumber daya manusia, secara keseluruhan tingkat pencapaian rata-rata 4,2 yang dapat diartikan bahwa responden cenderung lebih baik dalam menjawab item pernyataan.

Pada pernyataan soal nomor 3 Diperlukan keterampilan (skill) diluar pengetahuan formal dalam mendukung kerja yang berkualitas memiliki nilai rata-rata 4,0. Hasil rata-rata tersebut di bawah nilai rata-rata keseluruhan 4,2 hal tersebut dikarenakan dalam seleksi test masuk masing-masing perbankan syariah tidak mempersyaratkan calon karyawan harus memiliki keterampilan (skill) diluar pengetahuan pendidikan formal. Pernyataan soal nomor 4 Menjaga sikap dan berperilaku yang baik sebagai salah satu penentu keberhasilan dalam bekerja memiliki rata-rata 4,1. Hasil rata-rata tersebut di bawah nilai rata-rata keseluruhan 4,2 hal tersebut dapat diartikan bahwa karyawan menganggap penting peran prilaku dalam kesuksesan dalam bekerja namun sebahagian masih meyakini bahwa poin ini bukan berdiri sendiri tapi ada poin lain yang juga sama penting dalam peraihan kesuksesan karyawan.

Pernyataan soal nomor 6 dimana Kedisiplinan kunci utama dalam kesuksesan individu dalam bekerja memiliki rata-rata 4,1. Hasil rata-rata tersebut di bawah nilai rata-rata keseluruhan 4,2, hal tersebut dapat diartikan bahwa faktor kedisiplinan masih menjadi catatan penting yang perlu diperhatikan oleh para karyawan perbankan syariah dan mesti diupayakan 
peningkatannya. Pernyataan soal nomor 8 dan 9 "Tanggung Jawab dalam mengemban amanah mutlak diperlukan dalam bekerja" dan "Loyalitas pekerja sangat dibutuhkan oleh perusahaan" memiliki rata-rata 4,1 yang juga berada di bawah rata-rata keseluruhan, hal ini mengindikasikan bahwa tanggung jawab dan loyalitas belum menjadi konsen utama sebagai indicator peningkatan kinerja karyawan perbankan syariah.

Pada Lampiran Tanggapan Responden untuk Kualitas Sumber Daya Manusia juga dapat dilihat nilai rata-rata skor alternatif pilihan jawaban responden terhadap seluruh pernyataan yang berhubungan kualitas sumber daya manusia menunjukkan angka sebesar 4,2. Angka ini menunjukkan bahwa karyawan perbankan syariah yang ada di Aceh memiliki kualitas sumber daya yang bagus . Adanya kualitas sumber daya manusia yang baik perbankan syariah, menjadi modal pengembangan perbankan syariah di Indonesia dan selanjutnya menjadi perbaikan ekonomi masyarakat itu sendiri dengan adanya lembaga interdimediasi keuangan.

\section{Kinerja Karyawan}

Untuk melihat tanggapan responden terhadap item-item pernyataan yang terdapat pada variabel Kinerja Karyawan dapat dilihat pada Lampiran Tanggapan Responden untuk Kinerja Karyawan. Tanggapan responden terhadap kinerja karyawan, secara keseluruhan tingkat pencapaian rata-rata 4,2 yang dapat diartikan bahwa responden cenderung lebih baik dalam menjawab item pernyataan.

Pada pernyataan soal nomor 5 tentang Saya berhasil melaksanakan segala aktivitas pekerjaan dikantor dengan baik dikarenakan nilai-nilai moral keislaman yang saya terapkan dalam bekerja memiliki rata-rata 3,9. Hasil rata-rata tersebut di bawah nilai ratarata keseluruhan 4,2 hal tersebut menunjukkan bahwa nilai moral perlu lebih tingkatkan kehadirannya dalam ruh kerja karyawan khususnya perbankan syariah,. Pernyataan soal nomor 8 Saya berhasil menduduki posisi sekarang ini disebabkan karena saya bertanggung Jawab dalam mengemban amanah pekerjaan yang diberikan memiliki rata-rata 3,9. Hasil rata-rata tersebut juga di bawah nilai rata-rata keseluruhan 4,2 hal tersebut dapat diartikan bahwa tannggung jawab tidak menjadi sebab utama peningkatan kinerja.

Pada Lampiran Tanggapan Responden untuk Kinerja Karyawan juga dapat dilihat nilai rata-rata skor alternatif pilihan jawaban responden terhadap seluruh pernyataan yang 
berhubungan dengan kinerja karyawan yang menunjukkan angka sebesar 4,2. Angka ini menjelaskan bahwa kinerja karyawan yang dilakukan oleh pihak karyawan perbankan syariah yang ada di Aceh sudah bagus hanya saja perlu untuk beberapa poin indikator seperti perilaku, tanggung jawab dan loyatilas perlu di tingkatkan oleh para karyawan.

\section{Pengujian Instrumen Penelitian}

\section{Pengujian Validitas}

Penelitian ini melakukan pengujian validitas data secara statistik, yaitu dengan menggunakan uji Pearson Product-Moment Coeffisient of Coleration dengan bantuan software computer yaitu melalui program Statistic Package fos Social Science (SPSS) 15.0. Semua pernyataan dinyatakan valid karena nilai signifikansi berada dibawah 5\% hal ini ditunjukkan oleh hasil pengolahan data (terlampir).

Sedangkan jika uji validitas dilakukan secara manual maka nilai korelasi hasil perhitungan harus dibandingkan dengan nilai kritis kolerasi product moment sehingga menghasilkan pernyataan bahwa semua item memiliki kolerasi hitung > nilai $\mathrm{r}$ kritis kolerasi product moment (perhatikan tabel nilai kritis kolerasi $\mathrm{r}$ product moment untuk $\mathrm{n}=30$ pada lampiran), didapatkan bahwa seluruh pernyataan tersebut signifikan dan mempunyai validitas yang konstruk. Berikut ini tabel hasil uji validitas.

Tabel 1

\section{Hasil Uji Validitas}

\begin{tabular}{cccc}
\hline Item Pertanyaan & $\begin{array}{c}\text { Koefisien } \\
\text { Korelasi }\end{array}$ & $\begin{array}{c}\text { Nilai Kritis } \mathbf{r} \\
\mathbf{N = 3 0}\end{array}$ & Keterangan \\
\hline KSDM1 & 0.387 & 0.361 & Valid \\
\hline KSDM2 & 0.364 & 0.361 & Valid \\
\hline KSDM3 & 0.452 & 0.361 & Valid \\
\hline KSDM4 & 0.299 & 0.361 & Tidak Valid \\
\hline KSDM5 & 0301 & 0.361 & Tidak Valid \\
\hline KSDM6 & 0.424 & 0.361 & Valid \\
\hline KSDM7 & 0.475 & 0.361 & Valid \\
\hline KSDM8 & 0.195 & 0.361 & Tidak Valid \\
\hline KSDM9 & 0.409 & 0.361 & Valid \\
\hline
\end{tabular}


Peran sumber daya manusia (SDM) dalam perkembangan perbankan syariah: ...(Nilam Sari, Abrar Amri)

\begin{tabular}{cccc}
\hline Item Pertanyaan & $\begin{array}{c}\text { Koefisien } \\
\text { Korelasi }\end{array}$ & $\begin{array}{c}\text { Nilai Kritis } \mathbf{r} \\
\mathbf{N = 3 0}\end{array}$ & Keterangan \\
\hline KK1 & 0.312 & 0.361 & Tidak Valid \\
\hline KK2 & 0.511 & 0.361 & Valid \\
\hline KK3 & 0.575 & 0.361 & Valid \\
\hline KK4 & 0.307 & 0.361 & Tidak Valid \\
\hline KK5 & 0.359 & 0.361 & Tidak Valid \\
\hline KK6 & 0.432 & 0.361 & Valid \\
\hline KK7 & 0.497 & 0.361 & Valid \\
\hline KK8 & 0.581 & 0.361 & Valid \\
\hline KK9 & 0.411 & 0.361 & Valid \\
\hline & Sumber: data primer, diolah (2018) &
\end{tabular}

\section{Pengujian reliabilitas}

Untuk menilai kehandalan kuesioner yang digunakan, maka dalam penelitian ini mengunakan uji reliabilitas berdasarkan Cronbach $A$ hh ha yang lazim digunakan untuk pengujian kuesioner dalam penelitian ilmu sosial. Reliabilitas juga dilakukan secara statistik yaitu dengan menghitung besarnya nilai cronbach's alpha dengan bantuan program SPSS. Instrumen dalam penelitian ini dikatakan reliabel apabila nilai Cronbach Alpha lebih besar dari 0,50.

Uji reliabilitas memperlihatkan bahwa secara keseluruhan tingkat kehandalan telah memenuhi persyaratan. Untuk lebih jelasnya, besarnya nilai alpha pada masing-masing variabel diperlihatkan pada tabel berikut ini.

\section{Tabel 2}

\section{Hasil Uji Reliabilitas}

\begin{tabular}{lcl}
\multicolumn{1}{c}{ Variabel } & Cronbach alpha & Keterangan \\
\hline Kulaitas sumber daya $\left(\mathrm{x}_{1}\right)$ & 0,603 & Reliable \\
\hline Kinerja karyawan $(\mathrm{y})$ & 0,674 & Reliable \\
\hline
\end{tabular}

Sumber: data primer, diolah (2018)

Berdasarkan Tabel 2 dapat disimpulkan bahwa nilai alpha untuk masing-masing variabel berada di atas nilai Cronbach $A$ hh ha yaitu lebih besar dari 0,5. Pengukuran reliabilitas terhadap variabel dalam penelitian ini menunjukkan bahwa pengukuran keandalan memenuhi persyaratan $\alpha>0,5$. 
ljtihad: Jurnal Wacana Hukum Islam dan Kemanusiaan, Volume 18, No. 2, Desember 2018: 227-249

\section{Pengujian asumsi klasik}

Pengujian asumsi klasik dalam peneletian ini dilakukan untuk menguji model regeresi yang digunakan tidaklah bias. Adapun uji asumsi klasik yang diuji terdiri dari uji heteroskedastisitas, uji normalitas dan uji autokorelasi.

\section{Uji heteroskedastisitas}

Uji heteroskedastisitas bertujuan untuk menguji apakah terjadi ketidaksamaan variance dalam model regresi dari residual satu pengamatan ke pengamatan yang lain. Jika variance dari residual satu pengamatan lain tetap atau tidak berbeda, maka disebut homoksedastisitas dan jika berbeda disebut heteroskedasitisitas. Hasil uji heteroskedastisitas melalui grafik scatterplots dapat dilihat di gambar dibawah.

Berdasarkan gambar dibawah ini dapat dilihat bahwa titik-titik menyebar secara acak baik di atas dan di sekitar angka nol pada sumbu Y. Penyebaran titik-titik data tidak menghasilkan pola bergelombang melebar kemudian menyempit dan melebar kembali serta tidak menggambarkan suatu pola. Maka dapat disimpulkan bahwa tidak terjadi gejala heteroskedastisitas.

\section{Gambar 1 \\ Grafik Scatterplot}

Scatterplot

Dependent Variable: Kinerja_Karyawan

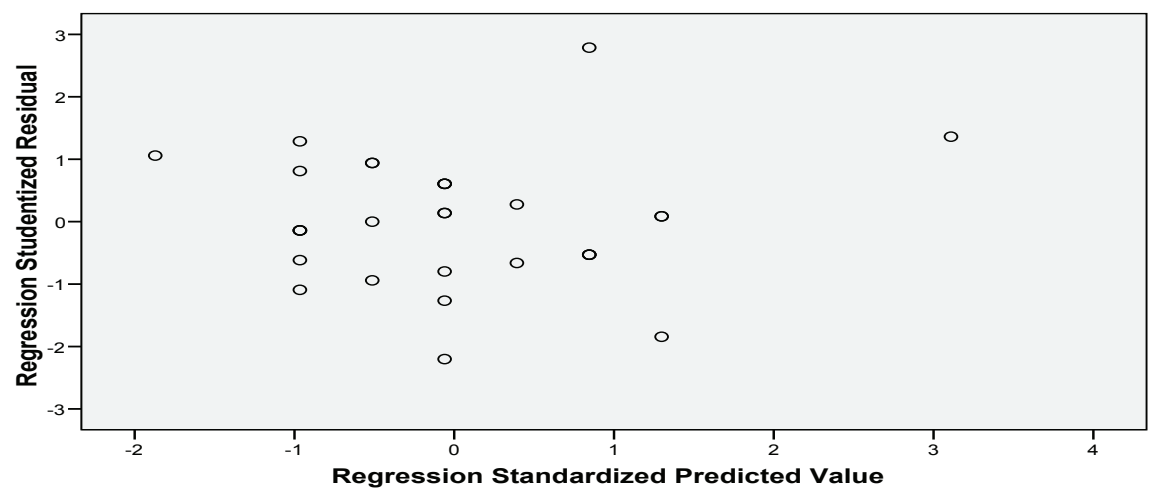


Peran sumber daya manusia (SDM) dalam perkembangan perbankan syariah: ...(Nilam Sari, Abrar Amri)

\section{Uji normalitas}

Uji normalitas bertujuan untuk menguji apakah variabel pengganggu atau residual terdistribusi normal dalam model regresi. Hasil pengujian dengan normal P-Plot berdasarkan gambar 1 menunjukkan bahwa titik-titik atau garis yang menunjukkan data sesungguhnya menyebar di sekitar garis diagonal, serta penyebarannya mengikuti arah garis diagonal. Normalplot terlihat bahwa titik-titik menyebar di sekitar garis diagonal dan mengikuti arah garis diagonal, ini menunjukkan bahwa data telah terdistribusi secara normal sehingga model regresi memenuhi asumsi normalitas. Dengan demikian dapat disimpulkan bahwa model regresi layak dipakai dan asumsi normalitas terpenuhi.

Gambar 2

Hasil Uji Normalitas

Normal P-P Plot of Regression Standarized Residual

\section{Dependent Variable: Kinerja Karyawan}

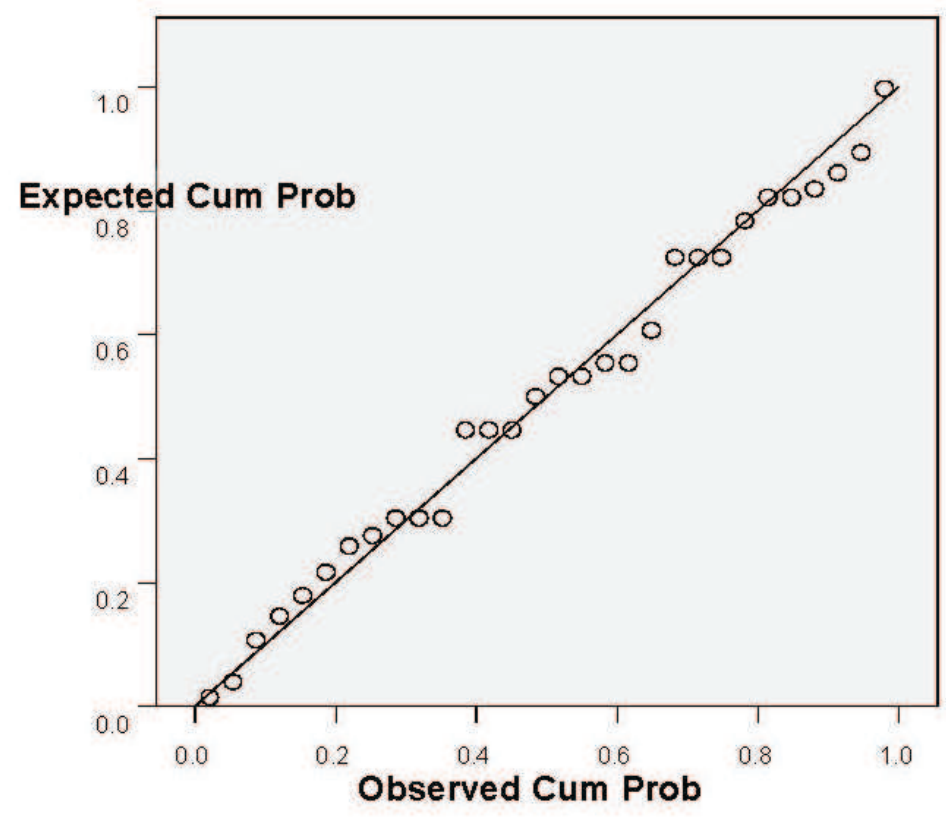




\section{Uji autokorelasi}

Pengujian asumsi klasik autokorelasi dilakukan dengan menggunakan pendekatan Statistik Durbin Watson (The Durbin Watson Statistic). Tujuan pengujian autokorelasi adalah untuk melihat apakah ada korelasi antara data observasi. Dasar pengambilan keputusan:

- Jika DW $<$ dL atau (4 - DW) $<$ dL maka terdapat autokorelasi

- Jika DW $>$ dU atau (4 - DW) $>$ dU maka tidak terdapat autokorelasi

- Jika dL $<$ d $<$ dU atau $\mathrm{dL}<(4-\mathrm{d})<\mathrm{dU}$ maka pengujian tidak meyakinkan atau tidak dapat disimpulkan.

Tabel 3

Hasil Uji Autokorelasi

\begin{tabular}{lllllll}
\hline Regresi & $\begin{array}{c}\text { Variabel } \\
\text { Dependen }\end{array}$ & $\begin{array}{c}\text { Variabel } \\
\text { Independen }\end{array}$ & $\begin{array}{c}\text { dU } \\
\text { (Batas } \\
\text { Atas) }\end{array}$ & DW & $\begin{array}{c}\text { dL } \\
\text { (Batas } \\
\text { Bawah) }\end{array}$ & Keterangan \\
\hline 1 & $\begin{array}{l}\text { Kinerja } \\
\text { Karyawan }\end{array}$ & $\begin{array}{l}\text { Kualitas Sumber } \\
\text { Daya Manusia }\end{array}$ & 1,264 & 1,965 & 1,134 & $\begin{array}{l}\text { Tidak terjadi } \\
\text { autokorelasi }\end{array}$ \\
& & & & &
\end{tabular}

Sumber: Data diolah (2018).

Berdasarkan tabel 3 diatas menunjukkan bahwa nilai DW untuk persamaan regresi sebesar 1,696. Untuk mengetahui apakah ada kolerasi antar observasi maka nilai ini akan dibandingkan dengan nilai tabel dengan menggunakan nilai signifikansi 5\%. Adapun jumlah observasi sebanyak $30(\mathrm{n}=30)$ dan jumlah variabel independen sebanyak $1(\mathrm{k}=1)$. Maka berdasarkan tabel statistik Durbin-Watson didapatkan sebesar 1,134 adalah nilai batas bawah (dL) dan 1,264 adalah nilai batas atas (dU). Merujuk pada uraian tersebut, maka untuk persamaan pertama dapat disimpulkan bahwa tidak terjadi terjadi autokorelasi, dikarenakan nilai DW lebih besar dari batas atas $(1,965>1,264)$ dan 4-DW lebih besar dari dU yaitu $(2,035>1,264)$.

Hasil Pengujian Hipotesis

Untuk menguji apakah ada tau tidaknya pengaruh dari variabel bebas terhadap variabel terikat, dilakukan pengujian hipotesis. Berikut ini adalah tabel hasil pengujian dengan regresi linier sederhana terhadap variabel-variabel penelitian: 
Peran sumber daya manusia (SDM) dalam perkembangan perbankan syariah: ...(Nilam Sari, Abrar Amri)

Tabel 4

Pengaruh Variabel Independen terhadap Variabel Dependen

Persamaan Regresi Linear Sederhana

$\mathrm{Y}=10,898+0,705 \mathrm{X}+\varepsilon$

\begin{tabular}{lccccc}
\hline \multicolumn{1}{c}{ Nama Variabel } & B & $\begin{array}{c}\text { Standar } \\
\text { Error }\end{array}$ & $\mathbf{t}_{\text {hitung }}$ & $\mathbf{t}_{\text {tabel }}$ & Sig \\
\hline Konstanta (a) & 10,898 & 6,983 & 1,561 & 2,048 & 0,130 \\
\hline Kualitas Sumber Daya Manusia $\left(\mathrm{x}_{1}\right)$ & 0,705 & 0,183 & 3,859 & 2,048 & 0,001 \\
\hline
\end{tabular}

a. Predictor: (Constant):

Koefisien Korelasi $(\mathrm{R})=0,589^{a}$

Kualitas Sumber Daya Manusia

Koefisien Determinasi $\left(\mathrm{R}^{2}\right)$

$$
=0,347
$$

b. Dependent Variabel:

Kinerja Karyawan.

Adjusted $\left(\mathrm{R}^{2}\right) \quad=0,324$

Sumber : Data diolah (2018).

Berdasarkan hasil perhitungan statistik dengan menggunakan bantuan program SPSS seperti terlihat pada tabel di atas, maka diperoleh persamaan regresi berganda sebagai berikut:

$$
\mathrm{Y}=10,898+0,705 \mathrm{X}+\varepsilon
$$

Berdasarkan tabel 4 di atas dapat diketahui hasil penelitian sebagai berikut:

\section{- Koefisien korelasi (R)}

Koefisien korelasi $(\mathrm{R})=0,589$ yang menunjukkan bahwa derajat hubungan (korelasi) antara variabel independen dengan variabel dependen sebesar $58 \%$. Artinya kinerja karyawan mempunyai hubungan yang kuat dengan kualitas sumber daya manusia $(\mathrm{X})$, karena diperoleh nilai koefisien korelasi lebih besar dari 0,5.

\section{- Koefisien Determinasi $\left(\mathbf{R}^{2}\right)$}

Koefisien Determinasi $\left(\mathrm{R}^{2}\right)=0,347$ Artinya sebesar 34\% perubahan-perubahan dalam variabel dependen kinerja karyawan dapat dijelaskan oleh perubahan-perubahan dalam kualitas sumber daya manusia (X). Sedangkan selebihnya yaitu sebesar $66 \%$ dijelaskan oleh faktor-faktor variabel lain yang tidak dimasukkan dalam model penelitian ini. 
ljtihad: Jurnal Wacana Hukum Islam dan Kemanusiaan, Volume 18, No. 2, Desember 2018: 227-249

\section{- Koefesien Regresi}

- Hasil pengujian didapatkan konstanta sebesar 10,898. Hal ini berarti bahwa jika kulaitas SDM $(\mathrm{X})$ dianggap konstan, maka besarnya kinerja karyawan adalah sebesar 10,898.

- Koefisien regresi kualitas sumber daya manusia (X) sebesar 0,705. Artinya bahwa setiap 100\% perubahan kualitas sumber daya manusia secara relatif akan menaikkan kinerja karyawan, sebesar 70\%, dengan asumsi variabel kualitas sumber daya manusia dianggap konstan dan tidak mengalami perubahan. Peningkatan kualitas sumber daya manusia akan menaikkan kinerja karyawan.

Hasil penelitian yang terhadap variabel kualitas SDM dan kinerja karyawan didapatkan $\mathrm{t}_{\text {hitung }}$ sebesar 3,859 dan $\mathrm{t}_{\text {tabel }}$ sebesar 2,048 hal ini menunjukkan bahwa $\mathrm{t}_{\text {hitung }}>\mathrm{t}_{\text {tabel }}$ dengan nilai signifikansi sebesar 0,001 yang berarti probabilitas diatas $\alpha=5 \%$. Hasil perhitungan statistik ini menunjukkan bahwa variabel kulitas SDM berpengaruh signifikan terhadap kinerja karyawan. Yang berarti semakin tinggi kualitas sumber daya manusia maka akan semakin tinggi kinerja karyawan pada perbankan syariah. Hal ini sebagaimana hasil penelitian: 1) "Pengaruh kualitas kerja dan kepuasan kerja karyawan terhadap kepuasan pelanggan pada TB Gramedia di Kota Palembang” (Jusuf R.H. Hasibuan, 2012). Hasil penelitian tersebut menunjukkan bahwa kualitas kerja dan kepuasan kerja karyawan berpengaruh terhadap kepuasan pelanggan pada TB Gramedia Kota Palembang. 2) "Pengarub etos kerja islam terhadap kinerja karyawan pada Bank Pembiayaan Rakyat Syariah Arta Mas Abadi Kabupaten Pati” (Mayya Puji, 2009). Hasil penelitian menunjukkan bahwa etos kerja islam berpengaruh positif terhadap kinerja karyawan Bank Pembiayaan Rakyat Syariah Arta Masa Abadi kabupaten Pati.

\section{Upaya peningkatan kualitas SDM perbankan syariah}

Dalam upaya meningkatkan kualitas sumber daya manusia perbankan syariah hal-hal yang dapat dilakukan antara lain sebagai berikut: Pertama, berdasarkan wawancara yang peneliti lakukan dengan Bapak Muhamammad Pimpinan cabang pembantu BSM Bireun, dikemukakan bahwa salah satu upaya yang bisa dilakukan dalam upaya peningkatan kualitas SDM perbankan adalah dengan memperluas dan meningkatkan kurikulum Ekonomi Islam khususnya pada perbankan syariah di institusi pendidikan. Kurikulum merupakan perangkat mata pelajaran yang sifatnya dapat berubah-ubah dan tidak kaku. Hal senada juga telah 
disampaikan oleh para cendikiawan pendidikan bahwa kurikulum bidang pelajaran Ekonomi Islam wajib diberikan penilaian setiap saat oleh institusi pendidikan yang melaksanakannya. Sudah pasti hal ini sangat berkaitan dengan sumber daya manusia yang dimiliki oleh sebuah institusi pendidikan atau perguruan tinggi. Dalam menyiapkan mutu SDM yang produktif, meskipun kurikulum dapat diubah, namun terdapat tolak ukur yang berfungsi dengan ringkasan konseptual berikut ini: 1. Meningkatkan mutu iman dan takwa 2. Meningkatkan mutu hitup 3. Meningkatkan mutu kerja 4. Meningkatkan mutu karya dan 5. Memperluas daya pikir.

Kedua, membangun, mengembangkan dan memajukan instansi pendidikan Ekonomi Islam. Terbuka ruang yang sangat besar bagi Perguruan Tinggi Islam baik Negeri ataupun Swasta untuk membangun dan mengembangkan fakultas/jurusan Ekonomi Islam dan berbagai bidang pelajaran lainnya yang sinkron dengan kepentingan perbankan syariah. Karena demikian, maka kemajuan dan pengembangan instansi pendidikan seperti perguruan tinggi akan sukses apabila bekolaborasi dengan pemerintah dalam hal ini yang berperan adalah Diknas, Depag dan perangkat lain yang berkaitan dengan hal administratif seperti lembaga pemberi izin; perguruan tinggi berperan sebagai lembaga penyelenggara; industri perbankan sebagai user. Ketiga indikator perlu bekerjasama agar memperoleh hasil yang bagus.

Ketiga, Melaksanakan DIKLAT/TOT Ekonomi Islam diantara yang menjadi sasaran kebijakan Diklat/TOT sebagaimana yang disampaikan oleh pincab Bank Muamalat Langsa, adalah bertujuan untuk: 1. Mendukung pertumbuhan melalui aspek penawaran (supply) dan permintaan (demand) secara merata 2. Mempererat pendanaan, manajemen dan sumber daya manusia bank syariah 3. Mengintensifkan tugas pemerintah sebagai pihak wewenang atas fiskal dan BI sebagai pihak wewenang perbankan dan moneter yang menjadi inisiator bagi pertumbuhan Ekonomi Islam 4. Dalam program akselerasi mengajak semua stakeholder perbankan syariah agar terlibat aktif sesuai dengan kemampuannya masing-masing. Pada poin 4 ini Lembaga pendidikan (Islam) dapat mengambil posisinya dalam mengembangkan dan meningkatkan perbankan Syari'ah. Bank Indonesia bergandingan dengan Perguruan Tinggi yang mengembangkan ekonomi islam dapat melaksanakan training bagi segenap pihak yang berkaitan dengan perbankan syariah. Untuk meraih target dalam jangka pendek pelatihanpelatihan seperti ini sangat penting. Sedangkan untuk mencapai tujuan dalam jangka panjang 
hal yang harus dilaksanakan adalah: meningkatkan kerjasama antara Bank Indonesia, Bank Syariah dan Perguruan Tinggi; menelaah kurikulum ekonomi islam/perbankan syariah; melakukan Pengembangan Kelembagaan Pendidikan Tinggi Ekonomi Islam pada UIN/ IAIN/STAIN dan manajemen SDM yang berorientasi pada Kepakaran dan Kompetensi.

Keempat, hal senada disampaikan oleh Pincab Bank Aceh Syariah- Lhokseumawe adalah dibutuhkan Komitmen Pemerintah. Sebagaimana dalam undang-undang dinyatakan: "bagi setiap individu mempunyai wewenang untuk meningkatkan taraf kehidupan melalui kebutuhan pokok yang tercukupi, memperoleh pendidikan serta mendapatkan ilmu pengetahuan dan teknologi yang berfaedah, seni dan budaya untuk mendapatkan kehidupan yang lebih berkualitas, adil dan sejahtera”. Sejurus itu dalam pasal 31 UUD 1945 dinyatakan: ayat (1) setiap individu di negara Indonesia memiliki hak untuk mengenyam pendidikan. (2) pendidikan dasar wajib diikuti oleh setiap warga negara dan pemerintah wajib membiayainya. (3) Pemerintah mengupayakan dan menyelenggarakan satu sistem pendidikan nasional, yang dapat meningkatkan keimanan dan ketakwaan .

\section{Penutup}

Berdasarkan pembahasan diatas, kualitas sumber daya manusia mempunyai pengaruh yang signifikan terhadap kinerja karyawan, Hal ini di dasari oleh pengolahan data yang menghasilkan $t_{\text {hitung }}$ sebesar 3,895 dan $t_{\text {tabel }}$ sebesar 2,048 hal ini menunjukkan bahwa $t_{\text {hitung }}>$ $\mathrm{t}_{\text {tabel }}$ dengan nilai signifikansi sebesar 0,001 atau nilai probabilitas $\alpha=5 \%$. Berdasarkan hasil perhitungan statistik menyatakan bahwa variabel kualitas sumber daya manusia mempunyai pengaruh yang signifikan terhadap kinerja karyawan. Dalam artian semakin tinggi kualitas sumber daya manusia maka akan semakin tinggi pula kinerja karyawan pada perbankan syariah.

Upaya peningkatan kualitas SDM perbankan dapat dilakukan melalui: 1) Pengembangan kurikulum Ekonomi Islam di lembaga pendidikan. Melakukan penilaian kurikulum bidang studi Ekonomi Islam secara rutin bagi institusi pendidikan yang melaksanakan bidang studi tersebut. 2) Mendirikan fakultas/jurusan Ekonomi Islam dengan berbagai bidang studi yang disesuaikan dengan kebutuhan pasar perbankan syariah. 3) Melaksanakan DIKLAT/TOT Ekonomi Islam bagi mahasiswa dan karyawan bank syariah. 4) Bank Indonesia berkolaborasi 
dengan Pergurua Tinggi yang mengembangkan Ekonomi Islam untuk menyelenggarakan berbagai training bagi seluruh elemen yang berkaitan dengan perbankan syariah. 5) Kerjasama antar institusi pendidikan, institusi perbankan, pemerintah dan masyarakat. Untuk meningkatkan mutu SDM dalam jangka pendek menyelenggarakan sosialisasi dan pelatihan tentang Ekonomi Islam khususnya perbankan suyariah. Sedangkan untuk waktu jangka panjang mengembangkan pendidikan yang bersinergi antara tiga indikator yang sangat berperan yaitu institusi perbankan, perguruan tinggi dan pemerintah.

Hasil penelitian diatas dapat diberikan saran bagi beberapa pihak. Pertama, Lembaga Pendidikan: Institusi pendidikan baik formal nonformal mulai dari sekolah dasar sampai perguruan tinggi perlu diadakan sosialisasi mengenai Ekonomi Islam yaitu melalui kurikulum pada institusi pendidikan tersebut. Melalui Sekolah Tinggi Ekonomi Syariah (STEI) diharapkan mampu menumbuhkan dan mengembangkan sumber daya Ekonomi Islam yaitu dengan melahirkan sarjana-sarjana ekonomi islam yang memahami hukum-hukum Ekonomi Islam, manajemen perbankan dan keuangan syariah. Agar dapat terjamin kualitas SDM yang berkecimpung di perbankan dan lembaga keuangan syariah non bank lainnya maka dibutuhkan sebuah lembaga sertifikasi SDM (sumber daya manusia). Kedua, Perbankan dan LKS: Untuk menyiapkan sumber daya manusia yang paham akan Ekonomi Islam maka semua elemen industri perbankan dan lembaga keuangan syariah non bank perlu bekerja sama untuk melakukan sosialisasi melalui simposium, lokakarya, seminar, dialog terbuka dan training lainnya yang dilakukan secara terus-menerus. Konsultan ekonomi islam dan training center juga perlu dibentuk agar dapat difungsikan sebagai pabrik sumber daya manusia yang siap mengambil peran di industri perbankan dan lembaga keuangan syariah lainnya. Perlu bercermin dan bersinergitas secara multilateral sumber daya manusia dengan negara-negara yang industri keuangan syariahnya sudah berkembang dan maju. Ketiga, Pemerintah: supaya institusi perbankan syariah tumbuh dan berkembang dengan baik maka dibutuhkan kebijakan dari pemerintah dan pengaturan berupa undang-undang. Termasuk dukungan dana dalam pengembangan sumber daya manusia. Selain itu Majelis Ulama Indonesia (MUI) dan Dewan Syariah Nasional (DSN) juga harus mendukung penuh untuk memberikan saran dan menegur SDM jika ada hal-hal yang tidak sesuai dengan ketentuan syariah. Keempat, Masyarakat: badan atau komunitas dakwah dapat berfungsi sebagai penyampai mengenai syariat islam, bahwa 
syariah Islam merupakan sistem hidup yang universal dan komprehensif dalam mengatur tatanan kehidupan. Dalam menciptakan dan melahirkan SDM yang unggul dan perkasa baik dari segi akidah, syariah, ataupun akhlak orang tua dan guru adalah orang yang memiliki peran sangat mudah dijangkau dalam hal ini.

\section{Daftar pustaka}

Amalia, Euis dkk. Potret Pendidikan Ekonomi Islam di Indonesia, Analisis Kurikulum, Model Pembelajaran, dan Hubungan dengan Kompetensi SDM Pada Industri Keuangan Syariah di Indonesia. Jakrta: Gramata Publishing, 2012.

Antonio, Syafii. Tantangan Profesionalisme Industri Keuangan Syariah dalam Gatra edisi Khusus Lebaran 2007 No 48 Tahun XIII, 11-24 Oktober 2007.

Arikunto, Suharsimi. Prosedur Penelitian Suatu Pendekatan Praktek. Jakarta: Rineka Cipta, 1993.

Bambang Hariadi. Manajemen Strategi. Malang: Bayumedia Publishing. 2005.

Buchari, Zainun. Manajemen Sumber Daya Manusia Indonesia. Jakarta: PT Gunung Agung, 2002.

Chalil, Zaki Fuad. Peran Ulama dan Cendikiawan Aceh Dalam Pengembangan dan Sosialisasi Ekonomi Syaria. Makalah Disampaikan pada acara Seminar Ekonomi Syariah oleh LDK al-Mizan Fakultas Ekonomi Unsyiah tanggal 18 Maret 2009 di Darussalam Banda Aceh.

Gomes, Faustino Cardosp. Manajemen Sumber Daya Manusia. Jakarta: Andi Offset, 2000.

Greer. Charles R. Strategy and Human Resources: a General Managerial Perspective. New Jersey: Prentice Hall, 1995.

Halimah, Cut Nur. Problematika SDM Perbankan Syariah. http://www.kompasiana.com/ imaaceh/problematika-manajemen-sumber-daya-manusia-sdm-di-perbankan-syariah_573804e5927e613605523ce8.Rabu 18 2016. Diakses Juli 2017.

Handoko, Hani. Manajemen Personalia Dan Sumber Daya Manusia, Edisi Kedua. Yogyakarta: Penerbit BPFE-UGM.

Hasibuan, Melayu SP. Manajemen Sumber Daya Manusia. Cetakan Kesembilan. Jakarta: PT Bumi Aksara, 2007.

Http://mediaindonesia.com/news/read/122587/kualitas-sdmindonesiamenigkat/ 201709-15. Diakses Agustus 2017.

IDB. Annual Report IDB Tabun 2008. Jeddah: IDB, 2008.

Kasmir. Bank dan Lembaga Keuangan Lainnya. Jakarta: Raja Grafindo Persada, 2001.

Laporan Institute for Management and Islamic Economic Development (IMIE), pada September 2012. Mangkunegara, Anwar Prabu. Manajemen Sumber Daya Manusia Perusahaan. Bandung: Remaja Rosdakarya, 2000. 
Peran sumber daya manusia (SDM) dalam perkembangan perbankan syariah: ...(Nilam Sari, Abrar Amri)

Narbuko, Chalid. Metodologi Penelitian. Jakarta: Bumi Aksara, 2005.

Nasution, S. Metode Rerearch. Bandung: Jemmars, 1991.

Nawawi, Hadari. Manajemen Stratejik Organisasi non Profit bidang Pemerintahan (dengan ilustrasi Bidang Pendidikan). Yogyakarta: Gajah Mada, 2000.

Notoatmojo, Soekidjo. Pengembangan Sumber Daya Manusia. Jakarta: Rineka Cipta, 1998.

Raharjo, Dawam. Intelektual, Inteligensia dan Perilaku Politik bangsa. Bandung: Mizan, 1999.

Evers, Hans-Dieter. Kondisi Indonesia, dibanding dengan Malaysia, Transition towards a Knowledge Society: Malaysia and Indonesia Compared, downloaded from www. uni-biedefeld,de/(de)/soz/iw/pdf/Evers_Transition. pdf. Tanggal 14 September 2012. Diakses Agustus 2017.

Prawirosentono, Suryadi. Kebijakan Kinerja Karyawan. Kiat Membangun Organisasi Kompetitif Menjelang Perdagangan Bebas Dunia. Edisi Pertama. Yogyakarta: BBFE, 1999.

Rizki, Odie. "Mengenal Peran dan Fungsi OJK dalam Mengatur dan Mengawasi Industri Jasa Keuangan Syariah”. Makalah. Dipresentasikan Agustus 2016.

Rivai, Veihzal dan Basri. Performance appraisal. Jakarta: PT Raja Grafindo Persada, 2005.

Rivai, Veithzal. Manajemen Sumber Daya Manusia Untuk Perusahaan. Jakarta: Grafindo, 2005.

Sedarmayanti. Sumber Daya Manusia dan Produktivitas Kerja. Bandung: CV. Mandar Maju, 2001.

Sjahdeini, Sultan Remy. Perbankekan Islam dan Kedudukan Dalam Tata Hukum Perbankkan Indonesia. Jakarta : Grafiti, 1999.

Sugiyono. Metode Penelitian Pendidikan (Pendekatan Kuantitatif, Kualitatif, dan R\&D). Bandung: Alfabeta, 2013.

Syaodih, Sukmadinata Nana. Metode Penelitian Pendidikean. Bandung: Remaja Rosda Karya, 2007.

Tim Peneliti UI. 'Presentasi Seminar Penelitian UI Tahun 2003”. Jakarta: UI, 2008.

Ulrich. Human Resource Champions: the next agenda for adding value and delivering results. USA: Harvard Bussiness School Press, USA, 1998.

UU Nomor 10 Tahun 1998 Tentang Perubahan atas UU.No.7 Thn 92 Tentang Perbankan.

UU Nomor 21 Tahun 2008 Tentang Perbankan Syariah. 
